\title{
Socialization of The Google Docs Usage as a File Collaboration Media During Pandemic
}

\author{
Misbahul Fajri1*, Bagus Priambodo ${ }^{2}$, Yuwan Jumaryadi ${ }^{3}$ iD \\ 1,2,3 Department of Information System, Faculty of Computer Science, Universitas Mercu Buana, Indonesia \\ *Corresponding author: Fajri989@gmail.com
}

\begin{abstract}
Abstrak
Teknologi yang berkembang pesat saat ini memudahkan manusia dalam melakukan pekerjaannya. Perkembangan teknologi informasi yang berkembang pesat menuntut kemampuan warga untuk dapat beradaptasi dengan perkembangan teknologi yang ada. Seseorang dapat melakukan pekerjaannya dari jarak jauh di rumah, tanpa harus datang ke kantor. Agar proses kerja jarak jauh menjadi lebih lancar, orang tersebut harus terlebih dahulu memahami penggunaan teknologi untuk membantu pekerjaannya. Di masa pandemi, pelatihan penggunaan Google Suite (Google Docs) sangat bermanfaat sehingga nantinya jika ada proses data yang harus di-share akan mempermudah proses update data. Kegiatan pengabdian masyarakat ini bertujuan untuk berbagi ilmu agar warga di Desa Meruya Utara dapat menambah pengetahuan dan meningkatkan kemampuannya dengan memanfaatkan teknologi informasi dan komunikasi dengan memperkenalkan Google Docs sebagai media kolaborasi file di masa pandemi. Metode yang digunakan adalah metode sosialisasi praktis dengan memberikan pelatihan Google Docs sehingga diharapkan melalui sosialisasi ini pemahaman dan penguasaan penggunaan Google Docs bagi warga di Meruya Utara dapat tercapai. Hasil kegiatan pengabdian masyarakat yang dilakukan menunjukkan bahwa para peserta kegiatan pengabdian masyarakat dapat memahami pentingnya penggunaan Google Docs di masa pandemi.
\end{abstract}

Kata Kunci: Google Suite, Pandemi, Teknologi

\section{Abstract}

Technology developing rapidly today makes it easier for humans to do their jobs. The rapid development of information technology demands citizens' ability to adapt to existing technological developments. One can do their work remotely at home without coming to the office. For the remote work process to be smoother, the person must first understand technology to help his work. During the pandemic, training on the use of Google Suite (Google Docs) is beneficial so that later if there is a data process that must be shared, it will make the process of updating data more accessible. This community service activity aims to share knowledge so that residents in North Meruya Village can increase their knowledge and improve their abilities by utilizing information and communication technology by introducing Google Docs as a medium for file collaboration during the pandemic. The method used is a practical socialization method by providing Google Docs training. It is hoped that through this socialization, an understanding and mastery of Google Docs for residents in North Meruya can be achieved. The community service activities' results showed that the participants of community service activities could understand the importance of using Google Docs during the pandemic.

Keywords: Google Suite, Pandemic, Technology

\section{INTRUDUCTION}

The development of human civilization is accompanied by the development of the method of delivering information in the future known as Technology (Komalasari, 2020; Montolalu \& Langi, 2018; Nursyam, 2019). Information technology continues to develop, but the delivery and form are more modern. Information technology is facilities and infrastructure (hardware, software, user) systems and methods for obtaining, transmitting, processing, interpreting, storing, organizing, and using data meaningfully (Hidayat \& Piliang, 2019; Nursyam, 2019; Wijasty et al., 2019; Yuniarti, 2012). Information technology refers to all forms of technology used to create, store, change, and use information in all its forms

$\begin{array}{lll}\text { History: } & & \text { Publisher: Undiksha Press } \\ \text { Received } & \text { : September 10, 2021 } & \text { Licensed: This work is licensed under } \\ \text { Revised } & \text { : September 12, 2021 } & \text { a Creative Commons Attribution 4.0 License } \\ \text { Accepted } & \text { : November 03, 2021 } & \text { Co } \\ \text { Published } & \text { : November 25, 2021 } & \text { CA }\end{array}$


(Aryani et al., 2019; Lengkong et al., 2018). The development of Information Technology is currently being felt in the world. Various fields, especially those related to computers (Ottenbreit-Leftwich et al., 2021; Shandilya et al., 2022; Wu et al., 2021). Information technology is one of the basic needs in almost all business sectors (Century et al., 2020; Liu et al., 2018; Pienimäki et al., 2021). Along with technological developments, computers which were previously a data processing tool system, have increased in capabilities (Dina \& Manivannan, 2021; Liu et al., 2018; O'Neil et al., 2010). Technology developing rapidly today makes it easier for humans to do their jobs. One can do their work remotely at home without coming to the office. For the remote work process to be smoother, the person must first understand technology to help his work.

Classification of the use of ICT into three types, namely: first, ICT as an educational media (tool) that is only as a complement to clarify the description presented (FernándezGutiérrez et al., 2020; Lange et al., 2020; León \& Castro, 2014). Second, ICT as a source, namely as a source of information and seeking information. Third, ICT as a learning system. Utilization of information technology or instructional computers and the internet for education and learning are: First, Learning about computers and the internet, namely computers can be used as learning objects, for example, computer science (Fitri \& Putro, 2021; Li, 2021; Park et al., 2020). She was second, Learning with computers and the internet, namely information technology that facilitates learning by the applicable curriculum in schools (Das, 2020; Eugenia et al., 2013; Yuniarti, 2012). Utilizing information technology tools requires equipment/devices that can be used to obtain information, such as computers/laptops and the internet (Gil-Flores et al., 2017; Kristinawati et al., 2018; Nguyen $\&$ Doytch, 2021). Indonesia experienced a relatively high growth of internet users, from around 2 million netters in 2000 out of a total population of about 206 million people $(+/-1 \%$ of the total population) and increased to 20 million letters from around 224 million people in 2007 (+/ - 10\% of the total population). The number of internet users increased again in 2013 to about 82 million netters out of a total population of 237 million Indonesians (around 40\%). Digital technology is the primary tool in all human activities, including education. The existence of technology facilitates the learning process and results in a shift in the working paradigm to WFH (Aditya, 2015; Gil-Flores et al., 2017; Karadag et al., 2021). Collaborative media can be utilized in this pandemic situation.

Media is an intermediary or delivery of messages from the sender to the recipient (Gever et al., 2021; Simamora, 2020; Suryadi et al., 2020). Media is one component of communication, namely as a messenger from the communicator to the communicant (Dewi \& Izzati, 2020; Hidayah et al., 2020; Linda et al., 2018). Media are all objects or components that can transmit messages from the sender to the recipient to stimulate thoughts, feelings, concerns, and interests (Azizah et al., 2017; Trilaksono et al., 2018; Udayani et al., 2021). One of the collaborative media used during this pandemic is Google Docs. Google Docs is a word processing service provided to Google users free of charge (Kopcha et al., 2020; Mohammed \& AL-Jaberi, 2021). Google Docs is another version that allows creating, editing, and sharing written documents online. Google Docs can be used to create a wide variety of essential documents. They start from meeting notes, cover letters, proposals, and more. The features are download, share, and offline (Ishtaiwa \& Aburezeq, 2015; Mansor, 2012). The download feature allows you to download the document being worked on. The share feature allows you to share documents with anyone. And the offline features of Google Docs can also be used offline. This offline feature will be handy, especially if you are traveling to a place not covered by a signal but still need to get work done.

In this pandemic period, training on the use of Google Suite (Google Docs) is beneficial. Later, if a data processor must be shared, it will facilitate the data update process (Espinosa-Garza et al., 2017; S.Mills, 2013). The benefits will be obtained through the 
socialization program for using Google Docs in North Meruya Village. It is hoped that employees in North Meruya Village will have the ability to use Google Docs as a medium for file collaboration, especially during this pandemic where many employees work from home. The utilization of information technology has encouraged the creation of innovation in several aspects of life by utilizing various applications such as collaboration for document files in the cloud, online meetings, and others that can be an option for employees or the public in North Meruya. This community service activity aims to share knowledge to improve the ability to use Google Docs as a medium that can be used to collaborate on files.

\section{METHOD}

This community service activity is carried out to increase the knowledge and abilities of residents in the northern Meruya sub-district in using Google Docs as an effort in the adaptation process to current technological developments. The implementation of this community service was carried out on February 10, 2021, and the implementation was carried out online using Google Meet media. The following are the stages in the implementation of community service activities: The target participants are employees in the North Meruya village; Limit the number of participants to 15-30 people; Give invitations to participants to be able to attend on a predetermined or mutually agreed day. The activity is carried out for one day. In the implementation of this activity the participants will be given theory about Google Docs. This activity will be divided into two stages, the first stage is filling out material by speakers regarding the use of Google Docs as a file collaboration media. Then the second stage is the question-and-answer stage related to the material presented so that the training provided can achieve maximum results. The methods used in this community service activity include: Provides general information and knowledge about Google Docs; Provide training and tutorials on using Google Docs as a file collaboration medium.

\section{RESULT AND DISCUSSION}

\section{Result}

The material is delivered in 1 day online through Google Meet media. The presenters of the material are the community service team itself which is adapted to their respective fields of expertise. Participants will be given information related to community service and its practices to explore absorption and understanding of the material. The material is presented by members of the Service Team according to the relevant field. The community service activities that have been carried out were also attended by 67 participants. At the end of the activity, a question-and-answer session was held, where participants were given the opportunity to ask questions, the PPM team leader closed the program and gave messages to all training participants to apply what they had learned. It is hoped that in the future Community Service, this program can be continued again and can reach a greater number of participants. The documentation is presented in Figure 1.

Overall, these activities run in a safe, orderly and controlled manner, so that the objectives to be achieved can be achieved. Each committee carries out its duties in accordance with the provisions of the chief executive. This activity has been successfully implemented. The activity also received a positive response from the participants. During the implementation of the event there were no major problems that could interfere with the course of the event. Participants showed a good response with a cooperative attitude between the committee and the instructors, making the atmosphere of the room more friendly, without 
any differences between the committee and participants. The Community Service Activities is presented in Figure 2.

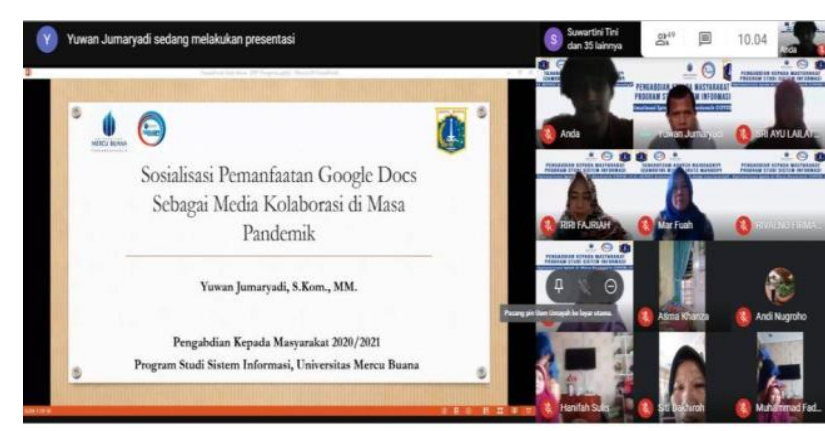

Figure 1. Google Docs Socialization

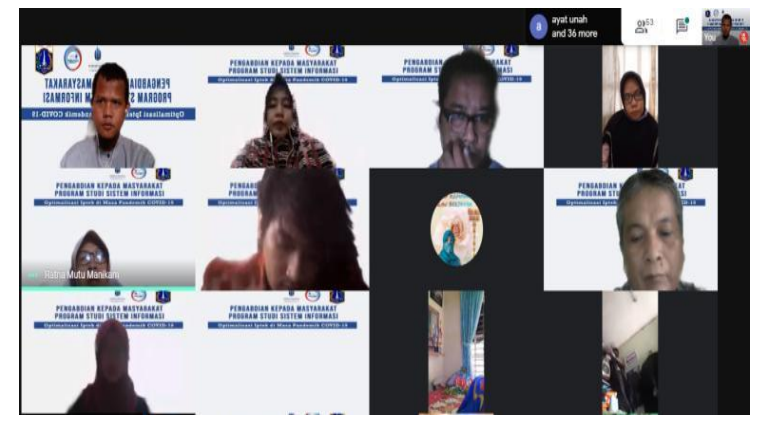

Figure 2. Community Service Activities

\section{Discussion}

Training is a series of individual activities in systematically increasing skills and knowledge to have professional performance in their fields (Destiniar et al., 2020; Elizar \& Tanjung, 2018). Training is a learning process that allows participants to carry out current work according to standards. The results of this training were that all participants were very enthusiastic about participating (Firmansyah \& Aima, 2020; Permatasari \& Hardiyan, 2018; Suryanto et al., 2018). Training is a process to improve employee competence and can train employees' abilities, skills, and knowledge to carry out work effectively and efficiently to achieve goals in a company. The purpose of the training is to improve skills and performance. This training teaches participants to apply google docs.

Google Docs is a word processing service provided to Google users free of charge (Kopcha et al., 2020; Mohammed \& AL-Jaberi, 2021). Google Docs is another version that allows creating, editing, and sharing written documents online. Google Docs can be used to create a wide variety of essential documents. They start from meeting notes, cover letters, proposals, and more. The features are download, share, and offline (Ishtaiwa \& Aburezeq, 2015; Mansor, 2012). The download feature allows you to download the document being worked on. The share feature allows you to share documents with anyone. And the offline features of Google Docs can also be used offline. This offline feature will be handy, especially if you are traveling to a place not covered by a signal but still need to get work done. The benefits will be obtained through the socialization program for using Google Docs in North Meruya Village. It is hoped that employees in North Meruya Village will have the ability to use Google Docs as a medium for file collaboration, especially during this pandemic where many employees work from home. The utilization of information technology has encouraged the creation of innovation in several aspects of life by utilizing various applications such as collaboration for document files in the cloud, online meetings, and others that can be an option for employees or the public in North Meruya.

\section{CONCLUSION}

Based on the results of the implementation of this community service activity and the description of the discussion above, it can be concluded that this training provides several materials related to efforts to provide information about Google Docs. In addition, the number of participants is proportional to the number of devotees, making this training more conducive. Based on the results of the questionnaires given before and after the implementation of community service activities, it can be concluded that there is an increase 
in citizen understanding about the importance of using Google Docs as a file collaboration media, especially during the current pandemic.

\section{ACKNOWLEDGEMENT}

The author would like to thank PPM Universitas Mercu Buana which has funded Community Service activities.

\section{REFERENCES}

Aditya, D. S. (2015). Embarking digital learning due to COVID-19: Are teachers ready? Journal of Technology and Science Education, 11(1), 104-116. https://doi.org/10.3926/jotse.1109.

Aryani, R., Suratno, T., Mauladi, M., \& Utomo, P. E. P. (2019). Implementasi Sistem Informasi Manajemen Arsip Di Fakultas Sains dan Teknologi Universitas Jambi. Jurnal Ilmiah Media Sisfo, 146-159. https://doi.org/10.33998/mediasisfo.2019.13.2.713.

Azizah, S., Khuzaemah, E., \& Rosdiana, I. (2017). Penggunaan Media Internet eXe-Learning Berbasis Masalah pada Materi Perubahan Lingkungan untuk Meningkatkan Hasil Belajar Siswa dalam kehidupan sehari-harinya dan juga psikomotor ( keterampilan ) siswa . Proses belajar dapat materi dan bahan belajar yang. Scientiae Educatia: Jurnal Pendidikan Sains, 2005, 197-213. https://doi.org/10.24235/sc.educatia.v6i2.1957.

Century, J., Ferris, K. A., \& Zuo, H. (2020). Finding time for computer science in the elementary school day: a quasi-experimental study of a transdisciplinary problembased learning approach. International Journal of STEM Education, 7(1). https://doi.org/10.1186/s40594-020-00218-3.

Das, K. (2020). Role of ICT for Better Mathematics Teaching. Shanlax International Journal of Education, 7(4). https://doi.org/10.34293/education.v7i4.641.

Destiniar, Mulbasari, A. S., Fuadiah, N. F., Octaria, D., Ningsih, Y. L., Retta, A. M. R., \& Isroqmi, A. (2020). Pelatihan Penyusunan Soal HOTS untuk Mengambangkan Kemampuan Pedagogik Guru. J-APDIPAMAS (Jurnal Pengabdian Kepada Masyarakat), 4(1), 163-170. https://doi.org/10.30734/j-abdipamas.v4i1.585.

Dewi, M. D., \& Izzati, N. (2020). Pengembangan Media Pembelajaran PowerPoint Interaktif Berbasis RME Materi Aljabar Kelas VII SMP. Delta: Jurnal Ilmiah Pendidikan Matematika, 8(2), 217. https://doi.org/10.31941/delta.v8i2.1039.

Dina, A. S., \& Manivannan, D. (2021). Intrusion detection based on Machine Learning techniques in computer networks. Internet of Things, 16. https://doi.org/10.1016/j.iot.2021.100462.

Elizar, \& Tanjung, H. (2018). Pengaruh Pelatihan, Kompetensi, Lingkungan Kerja Terhadap Kinerja Pegawai. Maneggio: Jurnal Ilmiah Magister Manajemen, 1(1), 46-58. https://doi.org/10.30596/maneggio.v1i1.2239.

Espinosa-Garza, G., Loera-Hernández, I., \& Antonyan, N. (2017). Functionality design in Google Docs as an interactive platform. Procedia Manufacturing, 13. https://doi.org/10.1016/j.promfg.2017.09.053.

Eugenia, Raymond, \& Leung, W. N. (2013). Ready for 21st-century Education - Pre-service Music Teachers Embracing ICT to Foster Student-centered Learning. Procedia Social and Behavioral Sciences, 73. https://doi.org/10.1016/j.sbspro.2013.02.047.

Fernández-Gutiérrez, M., Gimenez, G., \& Calero, J. (2020). Is the use of ICT in education leading to higher student outcomes? Analysis from the Spanish Autonomous $\begin{array}{llll}\text { Communities. Computers and Education, 157, } 103969 . & .\end{array}$ 
https://doi.org/10.1016/j.compedu.2020.103969.

Firmansyah, A., \& Aima, H. (2020). Pengaruh pelatihan, kompensasi, dan motivasi kerja terhadap kinerja karyawan. Journal FEB Unmul: Kinerja, 17(2), 172-185. https://doi.org/10.29264/jkin.v17i2.7050.

Fitri, Y., \& Putro, N. H. P. S. (2021). EFL Teachers' Perception of the Effectiveness of ICTELT Integration During the COVID-19 Pandemic. Proceedings of the International Conference on Educational Sciences and Teacher Profession (ICETeP 2020), 532(532), 502-508. https://doi.org/10.2991/assehr.k.210227.086.

Gever, V. C., Tunca, E. A., Boluwatife, A. A., Nwogbo, V. C., \& Chinweobo-Onuoha, B. N. (2021). Visual media and learning: Effect of interactive television instruction as an intervention strategy for improving the critical thinking skills and disposition of outof-school nomadic children in Nigeria. Learning and Motivation, 76. https://doi.org/10.1016/j.lmot.2021.101767.

Gil-Flores, J., Rodríguez-Santero, J., \& Torres-Gordillo, J. J. (2017). Factors that explain the use of ICT in secondary-education classrooms: The role of teacher characteristics and school infrastructure. Computers in Human Behavior, 68, 441-449. https://doi.org/10.1016/j.chb.2016.11.057.

Hidayah, N., Wahyuni, R., \& Hasnanto, A. T. (2020). Pengembangan Media Pembelajaran Gambar Berseri Berbasis Pop-Up Book Untuk Meningkatkan Keterampilan Menulis Narasi Bahasa Indonesia. Jurnal Pendidikan Dan Pembelajaran Dasar, 7(1). https://doi.org/10.24042/terampil.v7i1.6182.

Hidayat, A., \& Piliang, F. (2019). Rancang Bangun Sistem Informasi Penyewaan Lahan Parkir Berbasis Web Gis. Jurnal Sistem Informasi Dan Sains Teknologi, 1(2), 1-9. https://doi.org/10.31326/JURNAL SISTEK.V1I1.320.

Ishtaiwa, F. F., \& Aburezeq, I. M. (2015). The impact of Google Docs on student collaboration: A UAE case study. Learning, Culture and Social Interaction, 7. https://doi.org/10.1016/j.lcsi.2015.07.004.

Karadag, E., Su, A., \& Ergin-Kocaturk, H. (2021). Multi-level analyses of distance education capacity, faculty members' adaptation, and indicators of student satisfaction in higher education during COVID-19 pandemic. International Journal of Educational Technology in Higher Education, 18(1). https://doi.org/10.1186/s41239-021-00291-w.

Komalasari, R. (2020). Manfaat Teknologi Informasi Dan Komunikasi Di Masa Pandemi Covid 19. Tematik, 7(1), 38-50. https://doi.org/10.38204/tematik.v7i1.369.

Kopcha, T. J., Neumann, K. L., Ottenbreit-Leftwich, A., \& Pitman, E. (2020). Process over product: the next evolution of our quest for technology integration. Educational Technology Research and Development, 68(2), 729-749. https://doi.org/10.1007/s11423-020-09735-y.

Kristinawati, E., Susilo, H., \& Gofur, A. (2018). ICT Based-Problem Based Learning on Students' Cognitive Learning Outcomes. Jurnal Pendidikan Sains, 6(2), 38-42. https://doi.org/10.17977/jps.v6i2.11683.

Lange, S., Pohl, J., \& Santarius, T. (2020). Digitalization and energy consumption. Does ICT reduce energy demand? Ecological Economics, 176. https://doi.org/10.1016/j.ecolecon.2020.106760.

Lengkong, O., Wahyudi, A. K., \& Najoan, A. (2018). Media Informasi Brosur Fakultas Ilmu Komputer Universitas Klabat menggunakan Augmented Reality Dalam Bentuk Video. Jurnal Teknologi Informasi, 17(2). https://doi.org/10.33633/tc.v17i2.1621.

León, L. P. de, \& Castro, P. L. (2014). ICT in Career Guidance. A Case Study of a "Blended Learning" Career Guidance Programme for Music Students. Procedia - Social and Behavioral Sciences, 116. https://doi.org/10.1016/j.sbspro.2014.01.518.

Li, B. (2021). Ready for Online? Exploring EFL Teachers' ICT Acceptance and ICT Literacy 
During COVID-19 in Mainland China. Journal of Educational Computing Research, 073563312110289. https://doi.org/10.1177/07356331211028934.

Linda, Albeta, Masnaini, \& Sulismawati. (2018). The Effect Of Prezy And Exe-Learning Media On Chemical Learning Results. Jurnal Edusains, 10(1). https://doi.org/10.15408/es.v10i1.7204.

Liu, Y., Tong, Y., \& Yang, Y. (2018). The Application of Mind Mapping into College Computer Programming Teaching. Procedia Computer Science, 129. https://doi.org/10.1016/j.procs.2018.03.047.

Mansor, A. Z. (2012). Google Docs as a Collaborating Tool for Academicians. Procedia Social and Behavioral Sciences, 59. https://doi.org/10.1016/j.sbspro.2012.09.295.

Mohammed, M. A. S., \& AL-Jaberi, M. A. (2021). Google Docs or Microsoft Word? Master's students' engagement with instructor written feedback on academic writing in a cross-cultural setting. Computers and Composition, 62. https://doi.org/10.1016/j.compcom.2021.102672.

Montolalu, C., \& Langi, Y. (2018). Pengaruh Pelatihan Dasar Komputer dan Teknologi Informasi bagi Guru-Guru dengan Uji-T Berpasangan (Paired Sample T-Test). D'CARTESIAN, 7(1), 44. https://doi.org/10.35799/dc.7.1.2018.20113.

Nguyen, C. P., \& Doytch, N. (2021). The impact of ICT patents on economic growth: An international evidence. Telecommunications Policy. https://doi.org/10.1016/j.telpol.2021.102291.

Nursyam, A. (2019). Peningkatan Minat Belajar Siswa Melalui Media Pembelajaran Berbasis Teknologi Informasi Increased Interest in Student Learning Through Information Technology- Based Learning Media. Jurnal Penelitian Hukum Dan Pendidikan, 18(1), 811-819. https://doi.org/10.30863/ekspose.v18i1.371.

O’Neil, H. F., Chuang, S. H. S., \& Baker, E. L. (2010). Computer-based feedback for computer-based collaborative problem solving. In Computer-Based Diagnostics and Systematic Analysis of Knowledge. https://doi.org/10.1007/978-1-4419-5662-0_14.

Ottenbreit-Leftwich, A. T., Kwon, K., Brush, T. A., Karlin, M., Jeon, M., Jantaraweragul, K., \& Guo, M. (2021). The impact of an issue-centered problem-based learning curriculum on 6th grade girls' understanding of and interest in computer science. Computers and Education Open, 2. https://doi.org/10.1016/j.caeo.2021.100057.

Park, H., Kim, H. S., \& Park, H. W. (2020). A Scientometric Study of Digital Literacy, ICT Literacy, Information Literacy, and Media Literacy. Journal of Data and Information Science. https://doi.org/10.2478/jdis-2021-0001.

Permatasari, I., \& Hardiyan, H. (2018). Pengaruh E-Learning Sebagai Media Pelatihan dan Pengembangan Terhadap Kinerja Karyawan BCA KCU Tangerang. Jurnal Sisfokom (Sistem Informasi Dan Komputer), $1(1), \quad$ https://doi.org/10.32736/sisfokom.v7i1.275.

Pienimäki, M., Kinnula, M., \& Iivari, N. (2021). International Journal of Child-Computer Interaction Finding fun in non-formal technology education. International Journal of Child-Computer Interaction, 29, 100283. https://doi.org/10.1016/j.ijcci.2021.100283.

S.Mills, M. (2013). Collaborative presentations using Google Docs. The Plugged-In Professor, 1. https://doi.org/10.1016/B978-1-84334-694-4.50012-0.

Shandilya, S. K., Upadhyay, S., Kumar, A., \& Nagar, A. K. (2022). AI-assisted Computer Network Operations testbed for Nature-Inspired Cyber Security based adaptive defense simulation and analysis. Future Generation Computer Systems, 127. https://doi.org/10.1016/j.future.2021.09.018.

Simamora, R. M. (2020). The Challenges of Online Learning during the COVID-19 Pandemic: An Essay Analysis of Performing Arts Education Students. Studies in Learning and Teaching, 1(2), 86-103. https://doi.org/10.46627/silet.v1i2.38. 
Suryadi, I., Yanto, Y., \& Mandasari, N. (2020). Pengembangan Media Pembelajaran Interaktif Berbasis Pmri Menggunakan Macromedia Flash Profesional 8. Judika Education, 3(2), 40-49. https://doi.org/10.31539/judika.v3i1.1263.

Suryanto, A., Sukamta, S., Kusuma, D. A., \& Wardhani. (2018). Pelatihan Pembuatan Profil Desa Dengan Memakai Window Movie Marker Bagi Perangkat Desa Jangli Krajan Kecamatan Candisari Semarang. Rekayasa, 16(1). https://doi.org/10.15294/rekayasa.v16i1.15083.

Trilaksono, D., Darmadi, D., \& Murtafi'ah, W. (2018). Pengembangan Media Pembelajaran Matematika Menggunakan Adobe Flash Professional Berbasis Literasi Untuk Meningkatkan Kreativitas Siswa. AKSIOMA: Jurnal Program Studi Pendidikan Matematika, 7(2), 180. https://doi.org/10.24127/ajpm.v7i2.1428.

Udayani, N. K. Ar. T. K., Wibawa, I. M. C., \& Rati, N. W. (2021). Development Of E-Comic Learning Media On The Topic Of The Human Digestive System. Journal of Education Technology, 5(3), 472-481. https://doi.org/10.23887/jet.v5i3.34732.

Wijasty, F. A., Utami, L. D., Yunandar, R. T., \& Priyono, P. (2019). Aplikasi Sistem Informasi Raport Online (Studi Kasus: Mi Darul Muta'allimien Leuwiliang Bogor). Jurnal Ilmu Pengetahuan Dan Teknologi Komputer, 5(1). https://doi.org/10.33480/jitk.v5i1.685.

Wu, D., Wang, H., Huang, L., \& Wang, Y. (2021). Computer aided machining fixture design algorithm and software based on case learning for near-net-shaped jet engine blade. $\begin{array}{llll}\text { Journal of } & \text { Manufacturing }\end{array}$ https://doi.org/10.1016/j.jmapro.2021.07.057.

Yuniarti, D. (2012). Analisis Kesiapan Industri Manufaktur Teknologi Informasi dan Komunikasi (TIK) Dalam Negeri Untuk Mendukung Implementasi Green-ICT Pada Sektor Telekomunikasi. Buletin Pos Dan Telekomunikasi: Media Komunikasi Ilmiah, 10(3). https://doi.org/10.17933/bpostel.2012.100305. 